\title{
Strategi Pengembangan Merek Berorientasi Kearifan Lokal Belitung Timur
}

\author{
Vina Meliana ${ }^{1)}$, Mariah $^{2)}$ \\ Manajemen, Institut Teknologi dan Bisnis Kalbis \\ Jalan Pulomas Selatan Kav. 22, Jakarta Timur 13210 \\ ${ }^{1)}$ Email:vina.meliana@kalbis.ac.id \\ ${ }^{2) E m a i l: m a r i a h @ k a l b i s . a c . i d}$
}

\begin{abstract}
Community Service which is carried out to assist entrepreneurs in East Belitung to overcome the challenges of Covid-19. This PKM aims to provide knowledge namely branding strategy with local culture orientation. The method used are observation of needs, training and business screening practices for community service partners, namely 40 entrepreneurs. The result of implementing PKM is that entrepreneurs have input to develop their products, understand strong brands, know how to formulate brand development strategies and determine the type of e-commerce that fits their product characteristics and certain consumers.
\end{abstract}

Keywords: branding strategy, e-commerce, local, product development

\begin{abstract}
Abstrak: Pengabdian Kepada Masyarakat (PKM) yang dilakukan untuk membantu para pelaku usaha di Belitung Timur dalam mengatasi tantangan Covid-19.PKM ini bertujuan untuk memberikan wawasan berupa strategi pengembangan merek berorientasi kearifan local. Metode yang digunakan berupa observasi kebutuhan, pelatihan dan praktik screening business kepada mitra PKM yaitu para pelaku usaha sejumlah 40 orang. Hasil penyelenggaraan PKM adalah para pelaku usaha memiliki input untuk mengembangkan produknya, memahami merek yang kuat, mengetahui cara merumuskan strategi pengembangan merek dan menentukan tipe e-commerce yang sesuai dengan karakteristik produk dan konsumennya masing-masing.
\end{abstract}

Kata kunci: e-commerce, lokal, pengembangan produk, strategi merek

\section{PENDAHULUAN}

Negara Indonesia dan dunia masih menghadapi permasalahan kesehatan yang sangat kritis yaitu virus Covid-19. Pandemi Covid-19 yang awalnya muncul di Tiongkok pada akhir tahun 2019 hingga menyebar ke seluruh dunia membawa berbagai dampak, baik dari segi ekonomi, bisnis hingga keamanan. Dampak bagi perekonomian yaitu menimbulkan gelombang pemutusan hubungan kerja dan banyak perusahaan harus gulung tikar akibat rendahnya daya beli masyarakat. Selain itu, pandemi Covid-19 menimbulkan runtuhnya berbagai sektor industri serta terhambatnya distribusi sebagai akibat banyaknya wilayah yang menerapkan pembatasan produk dari luar negeri.

Pemerintah Indonesia terus berupaya untuk memperhatikan kesejahteraan masyarakat melalui penyaluran bantuan paket sembako, uang tunai dan pelatihan bagi yang mengalami PHK. Bantuan tersebut tidak cukup untuk memenuhi kebutuhan masyarakat karena nilainya semakin berkurang, mengingat besarnya nilai bantuan juga harus berbagi dengan dana penanganan Covid-19 di beberapa Rumah sakit rujukan.

Adanya penerapan new normal bagi industri penerbangan domestik pada akhir Mei 2020 membawa harapan akan perubahan terhadap kondisi industri lainnya (Uly, 2020). Kemudian adanya Pembatasan Sosial Berskala Besar (PSBB) pada bulan November 2020, membuka peluang bagi industri pariwisata untuk memperbaiki kinerja usahanya. Gubernur Bank Indonesia Perry Warjiyo menyatakan bahwa ada tiga implikasi bagi Indonesia terkait pandemi COVID-19 yaitu pada sektor pariwisata, perdagangan dan investasi (Fitriani, 2020). Salah satu daerah yang memanfaatkan aspek pariwisata sebagai sumber penghasilan daerah adalah Belitung Timur.

Belitung Timur merupakan salah satu wilayah yang menjadi tujuan wisata masyarakat. Potensi pariwisata yang sangat tinggi di Belitung Timur muncul dari adanya lokasi wisata Kampung Ahok dan Laskar Pelangi. Selain itu, Belitung Timur juga memiliki banyak warung kopi. Warung kopi tersebut semakin popular sehingga membuat komoditi kopi Belitung Timur dikagumi. 
Di tengah pandemi, banyak pelaku usaha di Belitung Timur yang merugi akibat Covid-19. Sejumlah pelaku usaha menghentikan produksinya karena tidak adanya permintaan dari konsumen. Konsumen lebih beralih kepada sektor primer untuk memenuhi kebutuhan sehari-hari. Adanya kondisi tersebut, maka diperlukan kegiatan Pengabdian Kepada Masyarakat guna memberikan pengetahuan serta motivasi kepada pelaku usaha setempat dalam menghadapi pandemi Covid-19.

Di tengah pandemi Covid-19, pelaku usaha dituntut untuk dapat bertahan serta menangkap peluang usaha baru. Kecermatan dan strategi yang dibutuhkan setiap pengusaha guna menekan dampak yang ditimbulkan sebagai akibat dari pandemi. Lebih lanjut, strategi dalam bertahan dan menangkap peluang usaha dapat dilihat dari segi pengelolaan keuangan serta bagaimana melakukan pemasaran untuk menjangkau pelanggan.

Adanya inisiatif para pelaku usaha untuk mengembangkan usaha lain untuk beradaptasi dengan situasi Covid-19, membuat mereka membutuhkan pelatihan strategi pengembangan merek bagi produk UMKM. Strategi merek yang tepat akan bermanfaat untuk membuka awareness, attitude dan berdampak pada loyalitas dari konsumen.

Dampak Covid-19 pada sektor bisnis cukup mengkhawatirkan bagi para pelaku usaha di Belitung Timur. Permasalahan pertama adalah Pelaku Usaha Mikro, Kecil dan Menengah kesulitan dalam memahami strategi untuk menarik minat konsumen. Pelaku usaha yang sebelumnya hanya memanfaatkan kekayaan alam sebagai mata pencaharian, harus mengubah produk utamanya sehingga dapat dibeli tanpa harus bertatapan muka secara langsung. Produk berupa barang yang mulai dikembangkan belum memiliki merek yang menarik sehingga sangat sulit dikenal atau bahkan dijual ke masyarakat luas. Hal seperti itu berujung dengan penjualan kepada kerabat dekat saja.

Kemudian permasalahan kedua yaitu Pelaku Usaha Mikro, Kecil dan Menengah harus mengubah metode berjualan yang rutin digunakan pada masa sebelum pandemi covid-19. Adanya pandemi Covid-19 membuat para pelaku usaha harus beradaptasi dengan teknologi dan media sosial sebagai sarana untuk menjangkau konsumen. Sementara banyaknya platform market place dan sosial media di internet, menyebabkan kesulitan dalam memahami dasar pemilihan platform yang tepat untuk menjangkau konsumennya.

\section{METODE PELAKSANAAN}

\section{A. Strategi Merek}

Merek adalah nama dan atau simbol yang bersifat membedakan seperti logo, cap, atau kemasan dengan maksud mengidentifikasi barang atau jasa dari seorang penjual atau penjual tertentu yang mampu membedakannya dari barang-barang yang dihasilkan oleh para kompetitor (Aaker 2018:114). Merek yang dirintis dengan baik akan menciptakan kekuatan untuk melindungi produknya dari kompetitor dan menciptakan nilai bagi pemiliknya. Ciri-ciri merek yang kuat adalah menarik, mudah di ingat, mudah diucapkan, bermakna, memiliki legalitas dan bertahan lama.

Salah satu tahapan dasar membuat merek yang kuat adalah dengan menciptakan kesadaran merek. Kesadaran merek merupakan sebuah kemampuan yang dimiliki oleh masyarakat dalam mengenali dan mengingat akan keberadaan suatu produk dalam pasar dari berbagai aspek penilaian tersendiri. Kesadaran akan sebuah merek terdiri dari berbagai level berikut ini (Surachman, 2008:7).

1. Unaware Brand, merupakan kondisi dimana masyarakat tidak dapat mengenali merek yang ada di pasar atau inovasi yang telah dilakukan suatu merek terhadap produknya pada segmen pasar dengan tujuan untuk memikat minat beli masyarakat. Contohnya mayoritas masyarakat tidak mengetahui bahwa minuman Mizone juga diproduksi oleh Aqua.

2. Brand Recognition, merupakan kondisi kesadaran merek oleh konsumen jika mengingat petunjuk tertentu. Petunjuk dapat berupa logo, simbol, jingle lagu, bau dan lainnya. Dengan kata lain tahapan ini merupakan suatu langkah konsumen mulai mengenali ciri, manfaat, dan fungsi produk yang hadir di pasar.

3. Brand Recall, merupakan kondisi dimana konsumen dapat langsung menyebutkan merek tertentu ketika ditanyakan tentang produk tertentu

4. Top of Mind, merupakan suatu keberhasilan yang telah dicapai oleh merek dalam memikat hati konsumen. Jika merek telah mencapai posisi top of mind, maka merek tersebut selalu disebutkan pertama kali oleh konsumen, muncul pertama kali dibenak konsumen dan menjadi merek prioritas dalam memilih sebuah produk atau jasa.

Setiap produk memiliki nilai tersendiri ketika memiliki merek yang melekat terhadapnya. Strategi pengembangan merek dapat dilakukan melalui menciptakan kesadaran merek dan membangun 
citra merek yang sesuai baik dengan karakteristik produk ataupun keinginan dari pemiliknya. Citra adalah persepsi masyarakat terhadap perusahaan atau produk. Sedangkan citra merek adalah persepsi mengenai sebuah merek sebagaimana direfleksikan oleh asosiasi merek yang terdapat dalam benak konsumen (Kotler dan Keller, 2016:315).

Citra merek dapat membentuk persepsi positif dan kepercayaan konsumen terhadap sebuah produk sehingga akan memperkuat loyalitas merek. Merek bersifat kompleks, dan dapat menciptakan persepsi melalui berbagai cara berikut ini (Kotler dan Keller, 2016:316): 1). Atribut, suatu merek dapat membentuk atribut tertentu dalam pikiran konsumen; 2). Manfaat yang ditawarkan, manfaat merupakan atribut yang harus diterjemahkan menjadi manfaat fungsional dan emosional; 3) Nilai, merek mampu menyatakan tentang nilai dari pembuat atau produsen; 4). Budaya, merek dapat merepresentasikan budaya tertentu yang ingin diangkat oleh pemiliknya; 5). Kepribadian, merek dapat menjadi sebuah proyeksi akan kepribadian tertentu; dan 6). Pengguna, merek dapat mengesankan tipe konsumen tertentu.

\section{B. Pengembangan Produk}

Produk merupakan segala sesuatu yang dapat ditawarkan oleh pelaku usaha untuk memenuhi kebutuhan dan keinginan konsumen. Pada dasarnya dalam membeli suatu produk. Seorang konsumen tidak hanya membeli produk, akan tetapi juga membeli manfaat atau keunggulan yang dapat diperoleh dari produk yang dibelinya. Oleh karena itu, suatu produk harus memiliki keunggulan dari produk-produk yang lain, melalui pengembangan produk yang dilakukan secara kontinyu. Pengembangan produk adalah proses pencarian ide untuk barang dan jasa baru dan mengkorelasikannya kedalam tambahan lini produk yang berhasil secara komersial. Proses ini tidak mudah dan sering mendapat hambatan baik secara internal maupun eksternal.

Produk baru terdiri dari produk asli, produk yang ditingkatkan, produk yang dimodifikasi dan merek baru. Tahapan proses pengembangan produk baru yang bisa dilakukan adalah sebagai berikut (Kotler and Armstrong, 2018: 219): 1). Idea generation; 2). Idea screening; 3). Pengembangan dan pengujian konsep; 4). Analisis Bisnis; 5). Pengembangan produk; 6). Pengujian pasar; dan 7). Komersialisasi

\section{E-commerce}

Pemasaran merupakan suatu usaha untuk menyediakan dan menyampaikan produk dan jasa kepada konsumen dengan mempertimbangkan pada faktor lokasi, waktu serta harga yang tepat dengan sarana komunikasi yang unggul. Sarana komunikasi antara pelaku usaha dengan konsumen berubah seiring perkembangan teknologi dan informasi. Jika biasanya menggunakan iklan pada media televisi, koran, billboard, maka sekarang mulai beralih dengan komunikasi berbasis elektronik atau dikenal dengan istilah e-commerce.

Menurut Kotler dan Armstrong (2018:237) e-commerce merupakan bentuk usaha dari perusahaan untuk memasarkan produk dan jasanya serta membangun hubungan dengan pelanggan melalui media internet. Laudon dan Traver (2017:22-27) mengkategorikan e-commerce sebagai berikut.

1. Business to Business (B2B), merupakan jenis e-commerce terbesar yang berfokus pada penjualan ke bisnis lain. Proses transaksi B2B melibatkan perusahaan yang dapat bertindak sebagai pembeli atau penjual. B2B terdiri dari dua model bisnis utama yang digunakan yaitu net marketplace, yang meliputi e-distributor, perusahaan e-procurement, bursa dan konsorsium industri, dan jaringan industri swasta.

2. Business to Consumer (B2C), merupakan jenis bisnis online yang menjangkau konsumen individual. B2C mencakup pembelian barang ritel, travel, konten online dan jenis layanan lainnya.

3. Consumer to Consumer (C2C), merupakan jenis bisnis yang menyediakan media bagi konsumen untuk menjual satu sama lain, melalui sebuah penyedia platform.

4. Mobile e-commerce, merujuk penggunaan perangkat yang bersifat mobile untuk memungkinkan transaksi online melalui jaringan seluler dan nirkabel untuk menghubungkan smartphone/tablet ke internet.

5. Social e-commerce, merupakan e-commerce yang menggunakan jejaring sosial dan sosial media. Proses social e-commerce melibatkan penggunaan aplikasi mobile pengolahan pesan seperti Facebook Messenger, WhatsApp, BBM, dan lain-lain sebagai media berinteraksi antara penjual dengan konsumen.

6. Local e-commerce, berfokus melibatkan konsumen berdasarkan lokasi geografisnya. Pelaku usaha lokal menggunakan berbagai teknik pemasaran online untuk mendorong konsumen ke toko mereka. Pertumbuhan local e-commerce juga didukung oleh keberadaan transportasi online yang menyediakan layanan on-demand lokal seperti GOJEK.

\section{Kondisi Mitra}

Mitra merupakan para pelaku usaha di Belitung Timur, yang tergolong menengah kebawah sejumlah 
40 orang. Adapun usaha yang dijalankan bergerak di bidang bidang perdagangan, produksi makanan ringan serta kuliner. Para pelaku usaha ini rata-rata berpendidikan Sekolah Menengah Atas (SMA). Hal itu yang menyebabkan kurangnya wawasan dan pengetahuan dalam mengembangkan usahanya. Terlebih adanya force majeur Covid-19 membuat pelaku usaha di Kecamatan Manggar, Kabupaten Belitung Timur ini semakin sulit beradaptasi.

\section{E. Metode Pelaksanaan Kegiatan PKM}

Pelaksanaan kegiatan dilakukan secara daring kaena jarak antara Jakarta dan Kecamatan Manggar, Belitung Timur berjarak kurang lebih $485 \mathrm{~km}$. Selain itu adanya pembatasan sosial berskala besar (PSBB) dan larangan berkerumun secara masal. Metode pelaksanaan adalah melalui observasi kebutuhan mitra, pelatihan dan screening business. Metode pelatihan disampaikan berupa presentasi mengenai topik materi serta diskusi tanya jawab seputar kegiatan yang sudah dilakukan oleh para pelaku usaha UMKM dan keterbatasan serta hambatan dalam menjalankan usaha. Setelah itu ada praktik screening business. Materi yang disampaikan meliputi: 1). Identifikasi pembuatan merek yang kuat; 2). Strategi membangun merek; 3). Strategi pengembangan produk dan merek; 4). Potensi pemanfaatan teknologi digital berbasis e-commerce; dan 5). Praktik screening business

\section{HASIL DAN PEMBAHASAN}

Peran serta mitra pada rangkaian kegiatan pengabdian kepada masyarakat ini adalah sebagai penyedia akses pelatihan bagi para pelaku usaha di Kecamatan Manggar, Kabupaten Belitung Timur. Para mitra sangat terbuka pada proses observasi sebelum kegiatan dilakukan. Selain itu para pelaku usaha juga antusias mengikuti rangkaian kegiatan pengabdian kepada masyarakat walaupun via zoom.

Para pelaku usaha di Belitung Timur telah memiliki existing business yang berfokus pada pariwisata yaitu penginapan, wisata alam, warung kopi dan produk makanan ringan yang biasanya dinikmati oleh wisatawan lokal ataupun luar secara langsung. Adanya bencana Covid-19 membuat bisnis tersebut berhenti untuk waktu yang cukup lama. Para pelaku usaha perlu untuk memikirkan pengembangan produk baru sekaligus menciptakan kesadaran merek akan produk barunya.

Produk dapat berupa barang dan jasa. Dalam menghasilkan produk, hendaknya sesuai dengan kebutuhan dan keinginan konsumen. Produk yang lebih tepat dijual pada masa Covid-19 ini merupakan produk berupa barang, untuk mengurangi interaksi langsung antara pelaku usaha dan konsumen. Konsep idea generation yang diusulkan adalah berbasis kearifan lokal Belitung Timur. Salah satu jenis kopi yang cukup terkenal di warung kopi Belitung Timur adalah kopi hitam Manggar. Sayangnya, kemasan kopi Manggar ini masih sangat sederhana sehingga terlihat tidak menarik bagi konsumen. Selain itu mulai terlihat potensi penjualan hasil budidaya kopi jenis liberika dan robusta. Padahal jenis kopi ini biasanya ditanam pada dataran tinggi tapi ternyata dapat tumbuh dengan baik pada ketinggian 50m diatas permukaan laut. Tren kopi yang terjadi hampir diseluruh provinsi Indonesia, seharusnya dapat dimanfaatkan bagi para pelaku usaha ini untuk mempopulerkan kopi Belitung Timur yang memiliki cita rasa berbeda.

Selain itu Belitung Timur terkenal dengan olahan lautnya. Makanan ringan seperti aneka kerupuk ikn dan udang, keripik siput gonggong dan akar bahar dapat menjadi ide bisnis yang dapat dikembangkan secara serius. Begitu pula dengan aneka sambal seperti sambal rusip, sambal lingkung dan balacan. Adanya pembatasan untuk bepergian oleh Pemerintah tentunya menimbulkan rasa rindu pada makanan daerah sehingga wisatawan luar kota tentu akan senang jika dapat menikmati kembali makanan ringan ini.

Proses pengembangan produk baru ini dapat membagi lokasi distribusi sesuai domisili calon konsumen yang dibidik. Pelaku usaha perlu melakukan survei sederhana untuk memperoleh input dari konsumen tentang jenis produk yang diingankan, manfaat, harga dan lainnya. Setelah itu memperhatikan pengujian daya tahan produk, pengemasan produk yang menarik, anggaran usaha dan strategi merek yang tepat. Perumusan sebuah merek ini harus memenuhi beberapa syarat seperti mudah diucapkan, mudah di ingat, bermakna, memiliki kecenderungan untuk disukai. Jika pelaku usaha tidak memiliki kemampuan yang cukup untuk membuat logo dan kemasan produk yang menarik, maka banyak tersedia jasa di internet untuk membantu membuatnya dengan harga yang terjangkau. Pada kesempatan ini, pemateri juga bekerjasama dengan dosen DKV untuk membantu pembuatan logo bagi para pelaku usaha.

Merek ini juga berkaitan dengan citra merek yang mau diciptakan untuk produknya. Jika kemasan produk difoto secara bagus distudio, label merek terbuat dari stiker anti air, botol yang bagus maka mengesankan manfaat emosional bahwa produk ini eksklusif. Ataupun jika sebuah merek ingin 
menujukkan kepribadian tertentu dapat didukung melalui tagline. Misalnya pure coffee Belitung, yang ingin menunjukkan kebanggaan asli daerah.

Salah satu sisi positif yang terjadi pada masa Covid-19 ini adalah sudah semakin berkembangnya teknologi dan informasi. Pemerintah Jokowi sudah memastikan jaringan internet sudah menjangkau sampai ke pelosok daerah Indonesia. Adanya perkembangan e-commerce memudahkan penjualan produk lintas geografi dan waktu. Tetapi banyaknya jenis e-commerce harus disesuaikan dengan karakteristik produk dan target konsumen yang dituju. Misalnya untuk konsumen generasi Z yaitu anak SMA dan mahasiswa tentunya sudah akrab dengan social e-commerce seperti Facebook, Instagram, Twitter dan lainnya. Mereka juga punya tingkat kepercayaan yang lebih tinggi untuk bertransaksi secara online. Hal tersebut tentunya berbeda dengan generasi $\mathrm{X}$ yang terbiasa mengakses media konvensional dan cenderung mempertimbangkan risiko finansial. Hal itu membuat pendekatan sarana berjualan untuk generasi $\mathrm{X}$ menggunakan pihak ketiga seperti marketplace Shopee dan Tokopedia.

Selanjutnya juga dijelaskan implementasi Consumer to Consumer (C2C) yang dapat dilakukan untuk memperoleh efisiensi biaya distribusi. Para pelaku usaha di Belitung Timur dapat menawarkan reseller di berbagai daerah sehingga dapat mengurangi biaya ongkos kirim yang harus ditanggung oleh setiap konsumen. Materi yang disajikan cukup lengkap untuk membantu para pelaku usaha dalam merintis pengembangan produk dan mereknya. Kemudian dilakukan screening business untuk mengevaluasi produk yang saat ini dikelola oleh para pelaku usaha. Dan bagi yang ingin mencoba merintis usaha dengan produk yang baru, juga difasilitasi dengan akun Facebook agar pemateri dapat membantu mengatasi permasalahan yang muncul setelah rangkaian kegiatan Pengabdian Kepada Masyarakat ini berakhir.

\section{SIMPULAN}

Pelaksanaan kegiatan Pengabdian Kepada Masyarakat berjalan cukup baik. Adapun manfaat yang diperoleh oleh para pelaku usaha, selaku mitra yaitu: 1). Para pelaku usaha mendapat insight untuk melakukan pengembangan produknya; 2). Para pelaku usaha memiliki pemahaman merek yang kuat; 3).Para pelaku usaha memahami strategi merek bagi produk eksisting; 4). Para pelaku usaha termotivasi untuk membuat strategi berkelanjutan pengembangan merek bagi produk barunya; dan 5). Para pelaku usaha mampu menentukan sarana e-commerce yang sesuai dengan karakteristik produk dan konsumen yang dituju.

\section{DAFTAR RUJUKAN}

Aaker. (2018). Consumer Behaviour in Era Millenial. Medan: Lembaga Penelitian dan Penulisan AQLI.

Fitriani. (2020). "Bos BI ingatkan risiko Covid-19 Menjalar ke 3 sektor ini”, [online]. www.Ekonomi.Bisnis.com. Diakses 11 Juni 2020 dari https://ekonomi.bisnis.com/ $\mathrm{read} / 20200428 / 9 / 1233768 /$ bos-bi-ingatkan-risikocovid-19-menjalar-ke-3-sektor-ini.

Kotler, and Keller. (2016). Marketing Management 15th Global Edition Ed. England:Pearson.

Kotler, and Armstrong. (2018). Principles of Marketing 17th Edition. New Jersey:Pearson.

Laudon, K., \& Traver, C. G. (2017). E-Commerce. Harlow:Pearson.

Uly. (2020). "Penerapan New Normal Covid-19 di Penerbangan", [online]. www.kompas.com. Diakses 25 Januari 2021 dari https:/www.kompas.com/sains/ $\mathrm{read} / 2020 / 05 / 19 / 080400423 /$ penerapan-new-normalcovid-19-di-penerbangan-ini-saran-perdopsi?page=all.

Surachman. (2008). Dasar-dasar Manajemen Merek. Malang: Banyumedia Publishing. 